\title{
Rekonstrukcja historycznej rzeźby za pomocą DEM obszarów przed przekształceniami antropogenicznymi - wybrane przykłady z Polski Środkowej
}

\section{DEM-based reconstruction of historical earth's surface of areas before antropogenic transformation: selected examples from Central Poland}

\begin{abstract}
Streszczenie: Zaprezentowany artykuł jest przedstawieniem procesu prowadzącego do utworzenia modelu terenu, wybranych obszarów w Polsce Środkowej przed wielkopowierzchniowymi przekształceniami antropogenicznymi mającymi miejsce pół wieku temu. Celem badań była rekonstrukcja Cyfrowych Modeli Wysokościowych (ang. DEM) obszaru, który ze względu na przekształcenia antropogeniczne nie jest w chwili obecnej dostępny do badań za pomocą nowoczesnych metod zbierania informacji wysokościowej.

W artykule podano dokładne kryteria wyboru materiałów źródłowych wraz z określeniem układu odniesienia, daty wydania mapy i cięcia poziomicowego. W części głównej artykułu zaprezentowano na dwóch przykładach - największego kompleksu górniczo-energetycznego w Europie - KWB Bełchatów oraz Zbiornika Sulejowskiego, jako rezerwuaru wody do największego miasta Polski Środkowej - Łodzi - szczegółowy opis metodyki postępowania z mapami historycznymi oraz przebieg prac począwszy od wyboru odpowiednich map, przez ich skanowanie, kalibrację i wektoryzację po ostateczny efekt, jakim jest uzyskanie modelu terenu, traktowanego jako historyczny. W opracowaniu tym podkreślono celowość takich działań oraz wykorzystanie modeli DEM w praktyce oraz na analizie kierunków i wielkości przekształceń antropogenicznych rzeźby historycznej i współczesnej.
\end{abstract}

Słowa kluczowe: Cyfrowe Modele Wysokościowe, porównywanie rzeźby terenu, historyczny CMW, analizy GIS.

Abstract:

\begin{abstract}
The article is a presentation of the process leading to the creation of a terrain model of selected areas in Central Poland before anthropogenic transformations which took place half a century ago. The aim of this study was to reconstruction Digital Elevation Models (called DEM) of the area, which is not currently available for research using modern methods of gathering altitude information due to anthropogenic transformation. The work shows the exact criteria for the selection of source materials along with an indication of the frame of reference date of the map and contour line distance. The main part of the article presents two examples - the largest complex of open mining and energy sector in Europe - KWB Bełchatów and Sulejów Reservoir as a water reservoir for the biggest city of Central Poland - Łódź - a detailed description of the methodology for dealing with historical maps, and the course of work from the selection of appropriate maps, through their scanning, calibration and vectorization to the final result, which is to obtain a terrain model, treated as a historical one. This study highlights the advisability of such activities and the use of DEM models in practice and in the analysis of directions and scale of anthropogenic transformations of historic and contemporary relief.
\end{abstract}

Key words: Digital Elevation Model, comparing terrain models, historical DEM, GIS analyses.

\section{Wprowadzenie}

Rozwój technologii GIS (Geograficzne Systemy Informacyjne) umożliwia dostarczanie coraz dokładniejszych danych oraz konstruowanie na ich podstawie precyzyjnych modeli współczesnej rzeźby terenu. Z uwagi na to, że jest to stosunkowo młoda dziedzina nauki powoduje to, iż większość danych pochodzi z okresu współczesnego. Brak jest dokładnych danych historycznych pozwalających na konstrukcje modeli terenu pochodzących z różnych okresów, a powstałych na bazie map historycznych, wykonywanych w różnych i często nieporównywalnych metodach, skalach, odwzorowaniach, punktach odniesienia czy używania różnego cięcia poziomicowego. Porównywanie rzeźby terenu z różnych lat oraz tworzenie modeli z okresów historycznych daje możliwość badania efektów działania procesów geomorfologicznych. Ze względu na ograniczone możliwości czasowe porównywanych procesów, metodą tą możliwe bywa badanie działalności rzeźbotwórczej, której przebieg jest stosunkowo szybki, oczywiście biorąc pod uwagę zegar geologiczny. W literaturze spotykamy wiele przykładów tego typu badań. Dotyczą one np. dolin rzecznych, gdzie ze względu na dużą dynamikę procesów fluwialnych można badać kształt i przebieg koryta rzecznego na modelach pochodzących z różnych lat (James i in. 2012). Można także spotkać prace dotyczące rekonstrukcji położenia lodowców i ich zmienność w czasie. Takie opracowania pochodzące z terenów Alp opublikowali Viessmann i in. (2013) oraz Zasadni i Kłapyta (2014), którzy zrekonstruowali obraz lodowców tatrzańskich w czasie ostatniego glacjału. Dużą dynamiką charakteryzują się również procesy wulkaniczne, a znanym większości użytkowników GIS są modele wulkanu Mount St. Helens dostępne zarówno z okresu przed erupcją 18.05.1980 roku, jak i dzisiejsze. Ich porównanie dostarcza wielu ciekawych obserwacji dotyczących przebiegu i rozmiarów zachodzących procesów rzeźbotwórczych. Jednym z najatrakcyjniejszych miejsc do prowadzenia tego typu prac są obszary podlegające intensywnej działalności człowieka. Jego działalność rzeźbotwórcza - zarówno bezpośrednia, jak i pośrednia - może być przedmiotem badań polegających na tworzeniu i porównywaniu modeli rzeźby terenu. Ten wątek na przykładzie rekonstrukcji pierwotnej rzeźby obszaru Zespołu Staromiejskiego w Toruniu poruszony został przez Molewskiego i Juśkiewicza (2014). 
Chcąc pokazać przykłady rekonstrukcji historycznej rzeźby terenu na obszarach podlegających intensywnej działalności rzeźbotwórczej człowieka wybrano dwa obszary badań w regionie łódzkim. Pole badawcze nr 1 stanowi obszar największego kompleksu górniczo-energetycznego w Europie - KWB Bełchatów wraz z towarzyszącymi jej obiektami powstałymi w wyniku pracy kopalni oraz znajdującej się tam elektrowni bazującej na węglu brunatnym. Pole badawcze nr 2 stanowi dolina rzeki Pilicy na odcinku pomiędzy Sulejowem a Smardzewicami - obszaru dzisiejszego sztucznego Jeziora Sulejowskiego powstałego jako rezerwuar wody do największego miasta Polski Środkowej - Łodzi. Wybór obu obszarów badawczych podyktowany został faktem, że w obu miejscach pierwotna rzeźba terenu, w wyniku działalności gospodarczej człowieka, została zupełnie zniszczona i przekształcona.

Celem pracy jest rekonstrukcja za pomocą narzędzi z rodziny GIS rzeźby obszaru, który ze względu na przekształcenia antropogeniczne nie jest w chwili obecnej dostępny do badań za pomocą nowoczesnych metod zbierania informacji wysokościowej, tj. skaningu lotniczego, Lidaru - (Light Detection and Ranging). Stąd wynika, że istnieje potrzeba opracowania i zebrania metodyki postępowania w procesie budowy CMW (Cyfrowy Model Wysokościowy) na podstawie map historycznych. Jednocześnie praca ta dostarczy również danych umożliwiających utworzenie dwóch modeli terenów z regionu łódzkiego do badań naukowych, polegających na analizie przekształceń antropogenicznych rzeźby terenu.

\section{Wybór materiałów źródłowych}

Materiałem źródłowym do konstrukcji historycznego CMW są opracowania geodezyjne, mapy dokumentacyjne topograficzne i inne, na których zamieszczona jest informacja wysokościowa odpowiedniej jakości. Podczas ich wyboru w konkretnym przypadku przeanalizowano wady i zalety każdej potencjalnej mapy oraz oceniono jej stopień przydatności w digitalizacji. Podkreślono, że szczególnie ważne są takie cechy, jak skala oraz cięcie warstwicowe. Mając na uwadze, że tworzone modele w przyszłości będą służyły do analiz form geomorfologicznych - wybrano mape w możliwie jak największej skali, aby można było rozróżnić poszczególne formy. W tym kryterium zostało przyjęte założenie, że najmniejsza możliwa do wykorzystania skala to 1:25 000. Ważną z punktu widzenia badań historycznych powierzchni jest i cięcie poziomicowe na mapie, którego stanowi wyznacznik dokładności informacji wysokościowych i z tego powodu konieczne było wybranie mapy o jak najmniejszej wartości tego parametru. Kolejnym ważnym aspektem jest data wydania mapy i rodzaj odwzorowania. Do badań niezbędna była mapa wykonana w okresie sprzed budowy inwestycji, na których zaznaczono pierwotną rzeczywistą rzeźbę terenu, charakterystyczną dla okresu przed znaczącą jej transformacją. Wybrano jednocześnie takie mapy, które wykonano w nie za bardzo odległym czasie od planowej inwestycji, aby jej dokładność wykonania była akceptowalna.

Po przeanalizowaniu dostępnych materiałów archiwalnych wytypowanych obszarów badawczych dla obszaru doliny Pilicy wybrano Mapę Obrębową Powiatów w skali 1:25 000 z roku 1961, następnie mapę dokumentacyjną dla Zbiornika Sulejowskiego w skali 1:10 000 załączoną do opracowania „Zbiornik wodny Sulejów badania sedymentacji i aktualizacja pojemności" IMGW 2008 (rys. 1BC). Najmniejsze cięcie warstwicowe, jakie udało się odczytać z tych źródeł, to $1,25 \mathrm{~m}$. Obszar badawczy zawężono do kształtu Zbiornika Sulejowskiego, ze względu na to, że teren okoliczny nie przykryty wodą dostępny jest na mapach współczesnych oraz istnieje w TBD (Topograficzna Baza Danych) w komponencie NMT.

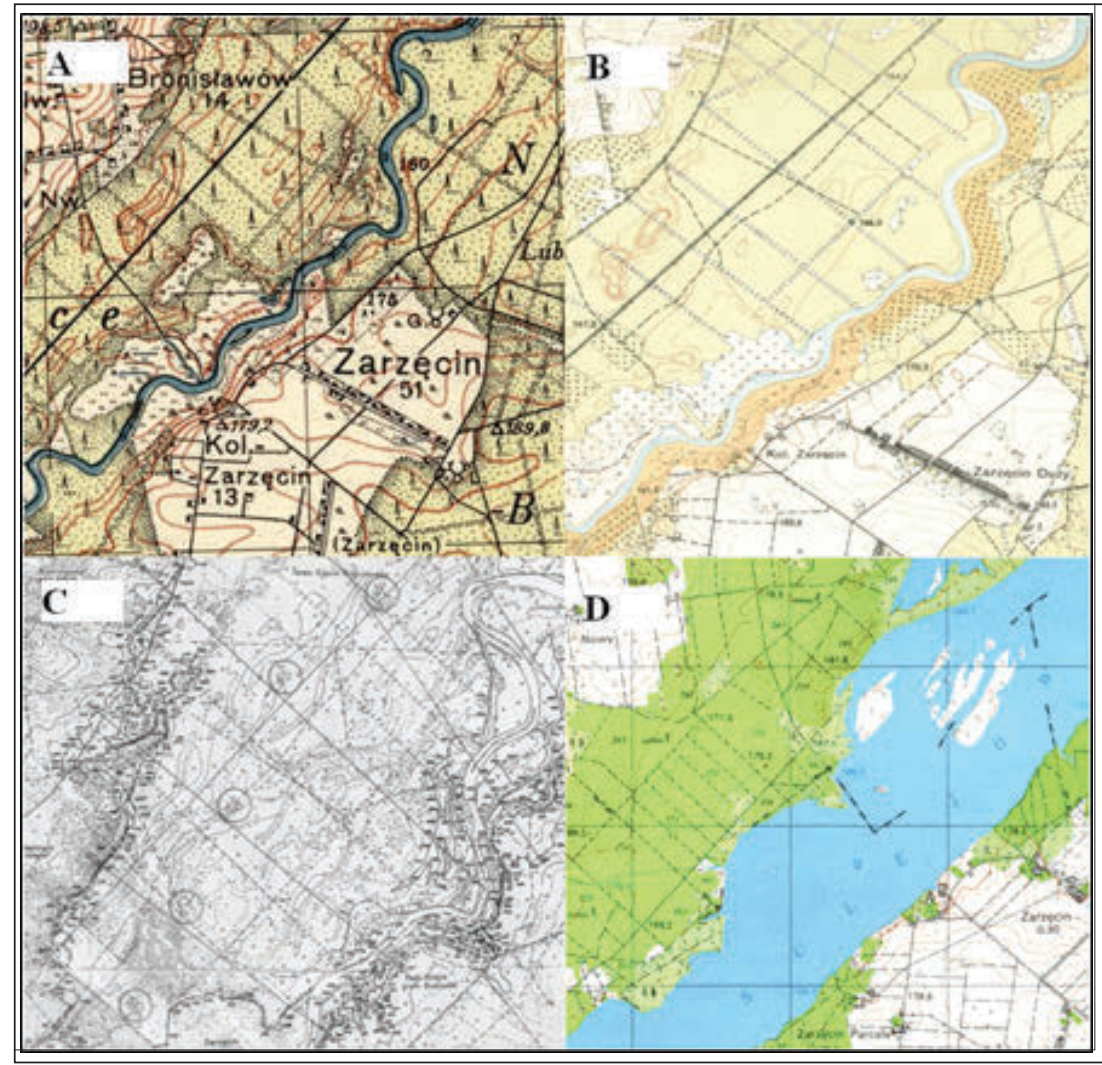

Rys. 1. Fragment doliny Pilicy w okolicach Zarzęcina na mapach: A - Mapa Taktyczna Polski WIG 1:100 000 - P43 S30 ark. Opoczno, rok wydania 1937, B - OMP 1:25 000 - Pow. Piotrków Tryb., ark. 3, rok wydania 1961 C - na Mapie dokumentacyjnej Zalewu Sulejowskiego zał. „Zbiornik wodny Sulejów badania sedymentacji i aktualizacja pojemności" IMGW 2008, D - Mapa topograficznej 1:25 000 ark. 133.11 ark. Włodzimierzów, rok wydania 1982

Fig. 1. A fragment of the Pilica valley in the area of Zarzęcin in maps: A - WIG - P43 S30 sheet. Opoczno 1937, B - OMP - Piotrków Trybunalski sheet 3, 1961, C-Documentary map of Sulejów Reservoir, D - on topographic map 1: 25000 sheet. 133.11, 1982 
W przypadku drugiego pola badawczego obszar analizy wyznaczony został tak, aby objąć odkrywkę kopalni węgła brunatnego Bełchatów oraz towarzyszące jej obiekty tj.: zwałowisko odkrywki Bełchatów, zbiorniki techniczne, elektrownia Bełchatów, odkrywka Szczerców i zwałowisko odkrywki Szczerców. Wyznaczony teren jest prostokątem o bokach $29 \mathrm{~km}$ oraz $12 \mathrm{~km}$, co daje powierzchnię $348 \mathrm{~km}^{2}$. Niestety, wiele z dostępnych materiałów kartograficznych zostało odrzuconych po ich weryfikacji. Mapa topograficzna w skali 1:10 000 - Arkusz 132.411 Wola Grzymalina opublikowana w roku 1986 ze względu na rok wykonania obejmowała już obszar początkowej fazy odkrywki „Bełchatów" (około $25 \%$ powierzchni wykopu). W tej sytuacji dokonano próby pobierania informacji wysokościowej z dwóch różnych opracowań w różnych skalach w celu zapełnienia miejsc, które nie były widoczne na mapie w skali 1:10 000 (rys. 2). Prace te zakończyły się niepowodzeniem ze względu na różnice w dokładności opracowań wynikające najprawdopodobniej z generalizacji map.

Ostatecznie wybór padł na niemieckie mapy, których kartowanie przypadło na lata 1929-1939. Zostały one wydane w roku 1944 przez niemieckie Dowództwo Wojsk Lądowych (Oberkommando des Heeres/Generalstab) (rys. 3C). Mapy te posiadają dość nietypowe cięcie warstwicowe 2,13 m, co było najlepszą wartością ze wszystkich możliwych dostępnych materiałów archiwalnych.

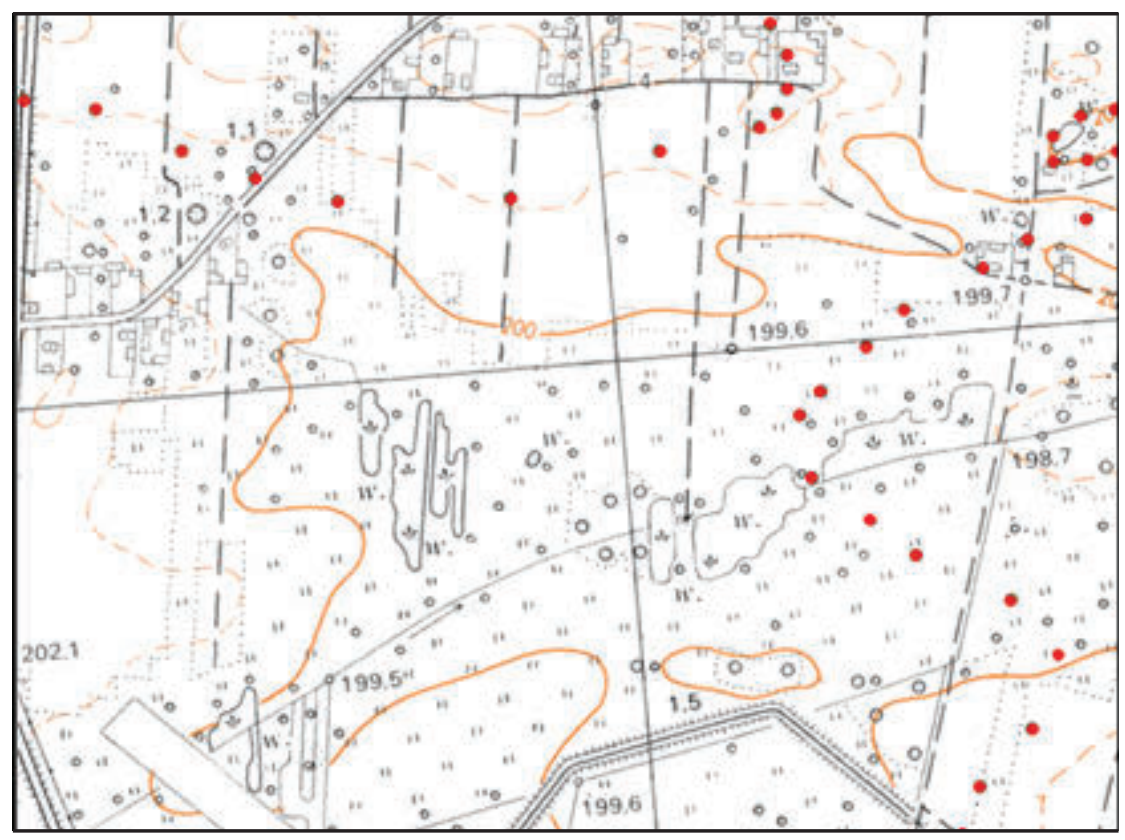

Rys. 2. Przebieg wektoryzowanej poziomicy 200 m n.p.m. z mapy w skali 1:25000 (oznaczono kropkami) na tle mapy w skali 1:10 000 (Arkusz 132.411 Wola Grzymalina)

Fig. 2. The course of digitised contour of $200 \mathrm{~m}$ asl from the maps in the scale of 1:25 000 (indicated by dots) on a map scale of 1:10000 (Sheet 132.411 Wola Grzymalina)

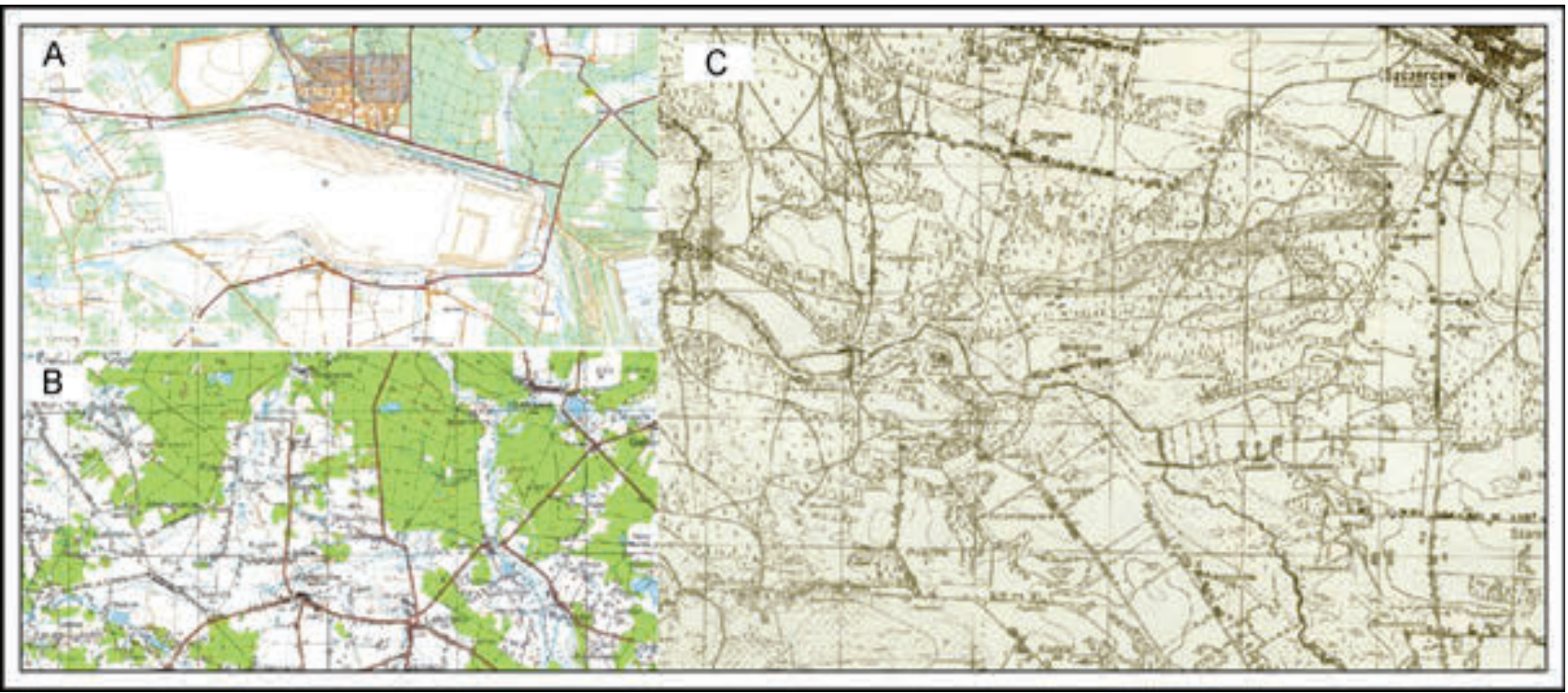

Rys. 3. Obszar dzisiejszej KWB Bełchatów. A - mapa topograficzna 1:25 000, arkusz 132.41 - Kopalnia Bełchatów, rok wydania 1983, B - mapa topograficzna 1:50 000, arkusz 132.4 - Kamieńsk, rok wydania 1973, C - mapa topograficzna w skali 1:25 000 - wydanie niemieckie, arkusz Szczerców (4328 H Scherzau), rok wydania 1944

Fig. 3. Contemporary area of KWB Bełchatów. A - topographic map of 1:25 000 sheet 132.41 - Kopalnia Bełchatów, 1983, B - topographic map 1:50 000 sheet 132.4 - Kamieńsk, 1973, C - topographic map 1: 25000 sheet Szczerców (4328 H Scherzau) 


\section{Metodyka i przebieg prac}

Po dokonaniu wyboru materiałów źródłowych prace prowadzone były zgodnie z metodami postępowania z mapami historycznymi (Jaskulski, Łukasiewicz, Nalej 2013; Wałek 2013; Jaskulski, Nalej 2014). Zgodnie z opracowanymi zasadami wykonano procesy skanowania map w rozdzielczości 300-400 dpi, aby otrzymać obraz zachowujący przejrzystość przy dużym przybliżeniu. Dzięki temu możliwa była identyfikacja poziomic w miejscach o dużych nachyleniach stoków. Otrzymane w ten sposób rastry połączono w jeden. Czynność tę wykonano w programie GIMP 2.8 na zasadzie docinania rastrów, a następnie dopasowywania ich do siebie. Aby móc korzystać z mapy podkładowej jako źródła danych wysokościowych należało umiejscowić ją w przestrzeni geograficznej, czyli nadać georeferencje. Odniesienie przestrzenne wykonano metodą wyznaczania punktów dostosowania na podstawie mapy referencyjnej. Do tego zadania została wybrana rastrowa mapa topograficzna w skali 1:25000, dostępna w serwisie www. geoportal.gov.pl. Dla każdej z map wyznaczono kilkanaście punktów dostosowania w miejscach charakterystycznych, niezmiennych na przestrzeni lat. Weryfikacji jakości procedury dokonano poprzez obliczenie średniego błędu RMS oraz zestawienie zrektyfikowanych rastrów ze współczesnymi mapami topograficznymi, biorąc pod uwagę charakterystyczne punkty i linie. Następnym krokiem jest wybór odpowiedniej korekcji graficznej, od rodzaju transformacji zależą błędy RMS oraz ewentualne zniekształcenia, jakim będzie poddana mapa. Przeprowadzone badania wykazały, że przy pracy z mapami historycznymi dopasowaniem dającym najlepsze wyniki jest transformacja adjust oparta na algorytmie łączącym transformację wielomianową z techniką interpolacji TIN (Jaskulski i in. 2013). Otrzymano w ten sposób materiał stanowiący podstawę do wektoryzacji polegającej w tym przypadku na wyznaczaniu punktów wysokościowych na podstawie rastrowego rysunku poziomic oraz wszelkiej innej informacji wysokościowej - punkty osnowy triangulacyjnej, miejsca o podanej wysokości. Działanie to polegało na utworzeniu w aplikacji ArcCatalog nowej warstwy punktowej, a następnie za pomocą narzędzia edycji umieszczaniu znaczników na podstawie mapy podkładowej (rys. 4, 5). W tabeli atrybutów tej warstwy została dodana kolumna, w której uzupełniany był atrybut wysokościowy dla każdego z otrzymanych punktów (Wałek 2014; Nowak 2015). W niektórych miejscach wprowadzono dodatkowe informacje wysokościowe nieopisane na rysunku poziomicowym (Badura, Przybylski 2004; Szubert 2008; Jaskulski, Szmidt 2014). Jednym z elementów podlegających takiej interpretacji są wody płynące, stojące oraz linie szkieletowe terenu (Jaskulski, Szmidt 2013).

Efektem tych prac było uzyskanie warstwy shp. punktów wysokościowych $\mathrm{z}$ informacjami w tabeli atrybutów $\mathrm{X}$, $Y, Z$ - gdzie „ $X$ " „Y" są współrzędnymi topograficznymi położenia punktu, zaś wartość „Z" - wysokością w m n.p.m. (rys. 4, 5). Przed dokonaniem kolejnych kroków niezbędna jest na tym etapie kontrola wprowadzonych danych w celu eliminacji błędów spowodowanych najczęściej złą interpretacją wartości wektoryzowanej poziomicy.

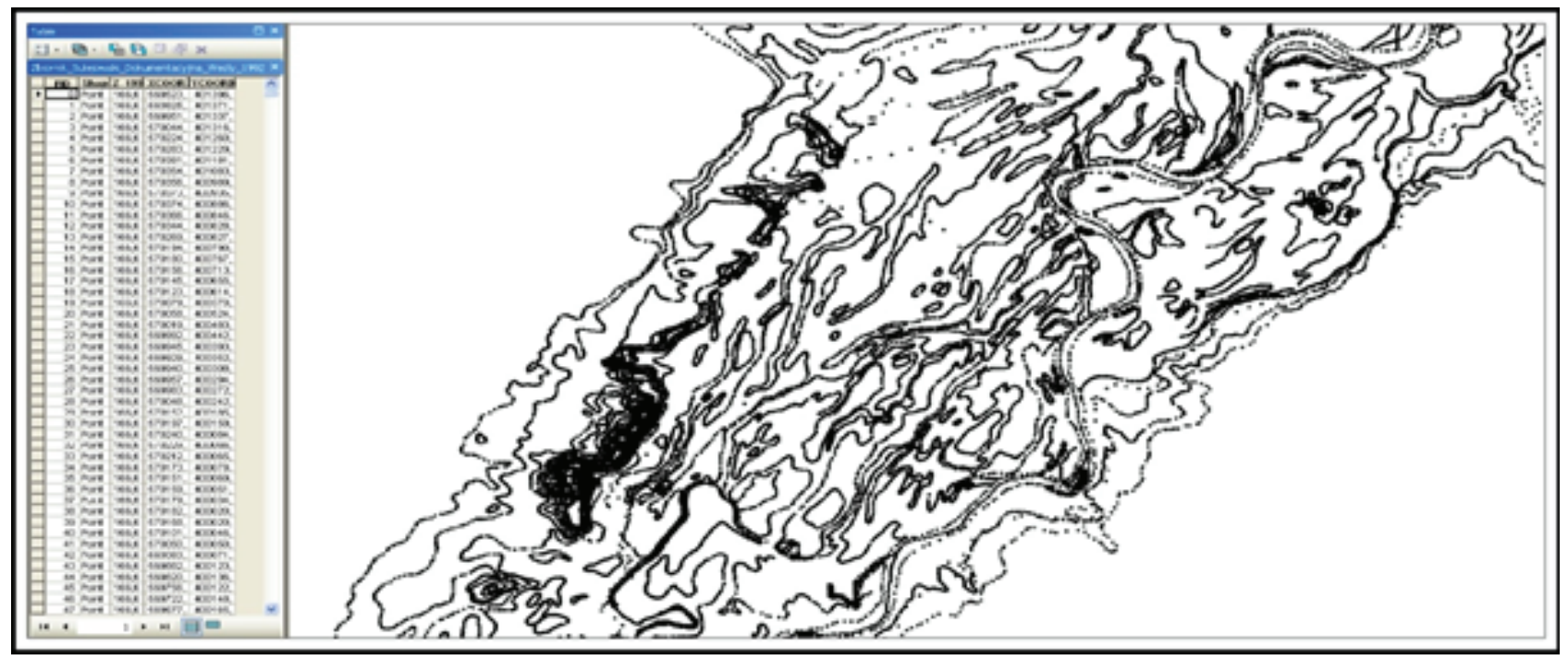

Rys. 4. Dolina Pilicy - obszar dzisiejszego Zalewu Sulejowskiego. Efekt końcowy wektoryzacji w postaci 46880 punktów z informacją wysokościową

Fig. 4. Pilica Valley - the area of today's Sulejów Reservoir. The final effect of vectorization as 46880 points with altitude information

\section{Wyniki}

W wyniku przeprowadzenia wyżej opisanych procesów otrzymano bazę danych, która może być użyta do prezentacji nieistniejącej dziś rzeźby terenu w różnych formach. Prawidłowe przedstawienie ukształtowania powierzchni wymaga odpowiedniej wizualizacji danych otrzymanych w wyniku tworzenia Cyfrowego Modelu Wysokościowego.
W przypadku zobrazowania rzeźby, dane punktowe zostały przekształcone na obraz rastrowy za pomocą interpolacji, czyli procedury szacowania wartości cechy w nieopróbowanych punktach, na obszarze objętym istniejącymi pomiarami. W celu wykonania tego procesu na danych wysokościowych najczęściej używa się najprostszych algorytmów interpolacyjnych naturalnych sąsiadów lub krigingu. Do modelowania powierzchni 2D, w tym 


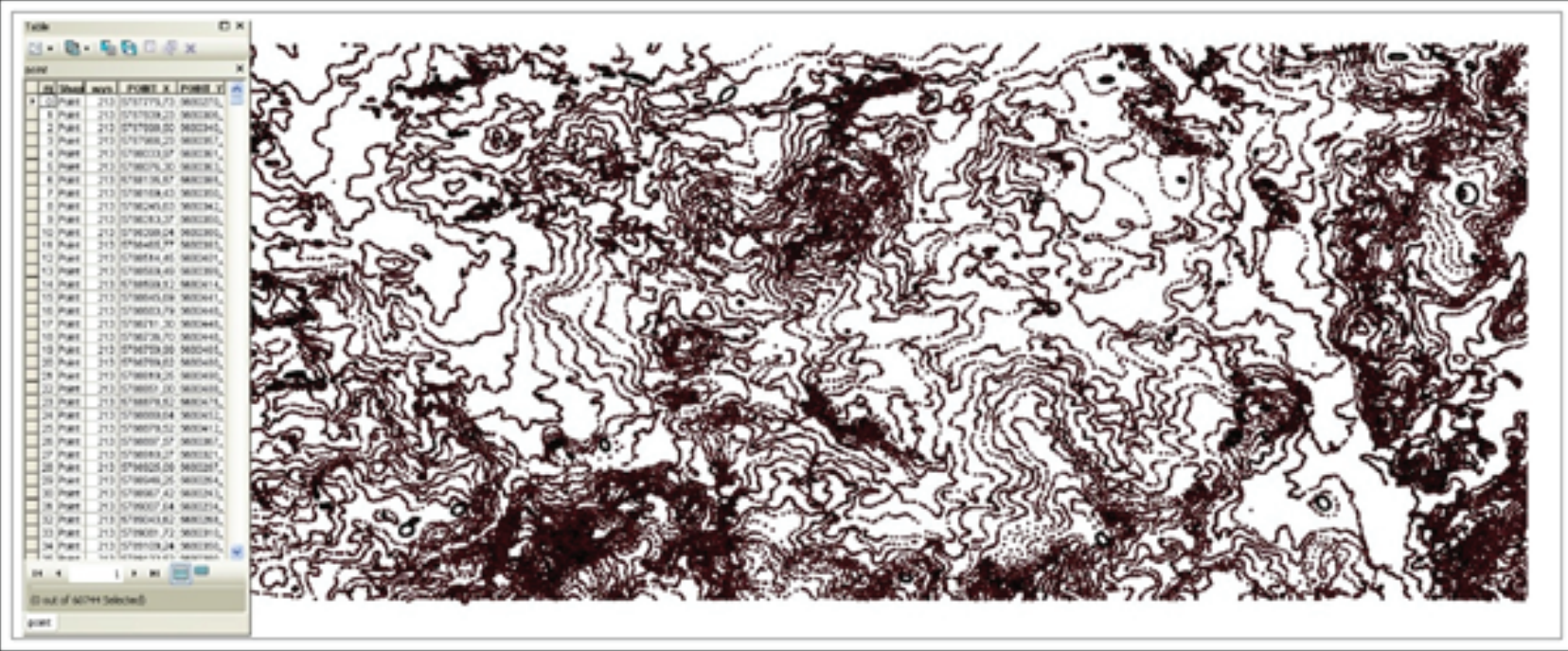

Rys 5. Obszar KWB Bełchatów z okolicami. Efekt końcowy wektoryzacji w postaci 60800 punktów z informacją wysokościową

Fig. 5. Area of open coal mine Bełchatów with the surrounding areas. The final effect of vectorization as 60800 points with altitude information

przypadku zastosowano metodę opisaną przez Sibsona (1981), znaną pod nazwami Closest Point, Closest Neighbour, Nearest Neighbour, Polygon Fitting itp. (Badura, Przybylski 2004; Mitka, Piech 2012). W ujęciu dwuwymiarowym obraz przedstawiony jest w formie mapy hipsometrycznej w standardowej skali barwnej z wykorzystaniem cieniowania. Oprogramowanie ArcGIS daje różne możliwości konstrukcji skal barwnych oraz kompozycji tworzonych map (rys. 6, 7), a także wizualizacji w postaci modeli trójwymiarowych 3D (Medyńska-Gulij 2010).

Uzyskany obraz rastrowy pozwala również na prosty dostęp do podstawowych danych statystycznych poprzez analizę jego histogramu. Na tej postawie można odczytać minimalną i maksymalną wysokość na analizowanym obszarze w okresie, gdy tworzona była mapa, ponadto wyznaczona zostaje średnia wysokość oraz odchylenie standardowe wartości. Wykonanie historycznego modelu wysokościowego obszaru otwiera także możliwości szeregu analiz, które prowadzą do utworzenia nowych map przedstawiających charakterystykę morfologii terenu. Za pomocą dołączonych do oprogramowania ArcGIS narzędzi Spatial Analyst dostępna jest możliwość wykonania badań parametrów charakteryzujących powierzchnię takich, jak: nachylenia, ekspozycje, krzywizny (Ewertowski, Tomczyk 2009). Powstała w ten sposób mapa spadków (rys. 8) czy mapa ekspozycji (rys. 9) pozwala na dokładniejsze poznanie charakterystyki powierzchni terenu. Korelując te modele z modelami uzyskanymi z danych teraźniejszych, za pomocą analiz rastrów pozwala na wykrywanie zmian zarówno ilościowych, jak i jakościowych terenu.

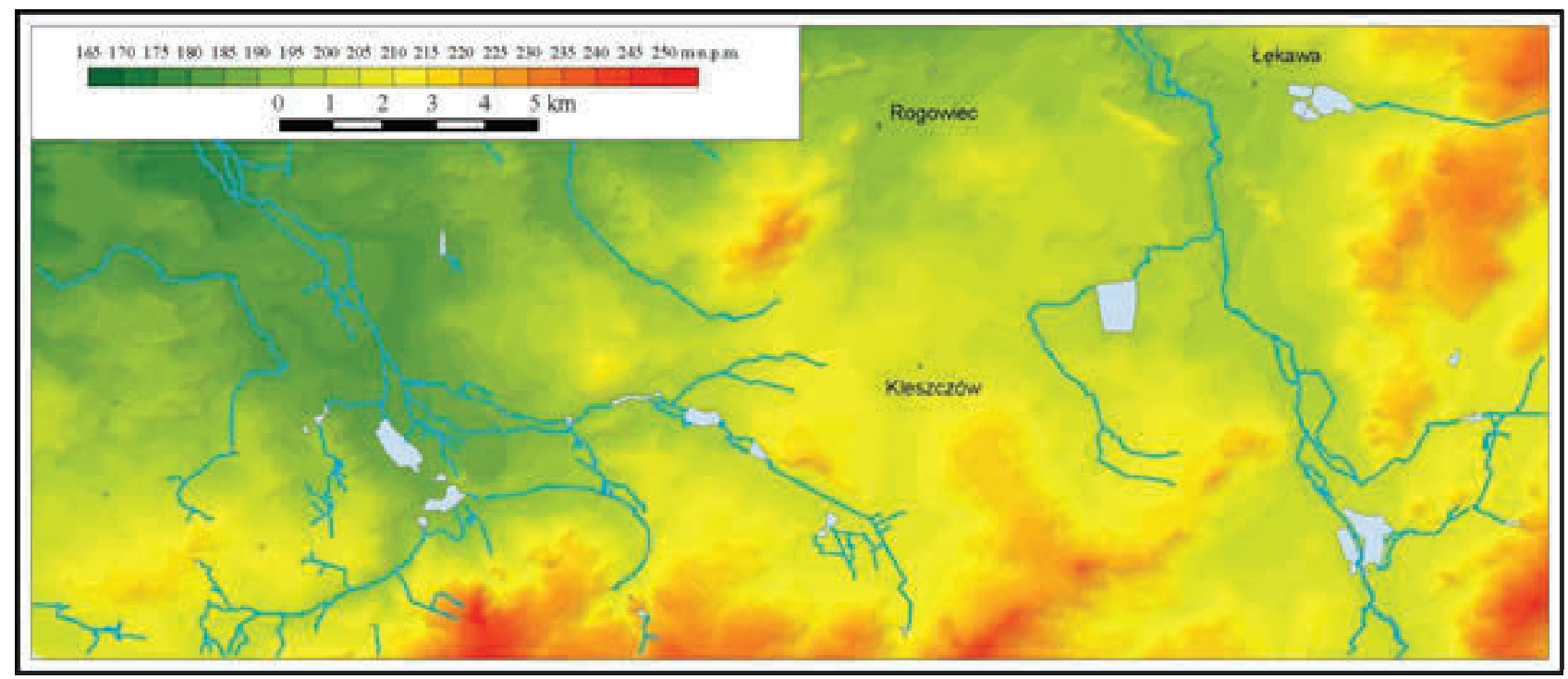

Rys. 6. Rzeźba terenu obszaru dzisiejszej KWB Bełchatów w okresie przedinwestycyjnym

Fig. 6. The relief of the area of Bełchatów brown coal opencast mine in the period before the investment 


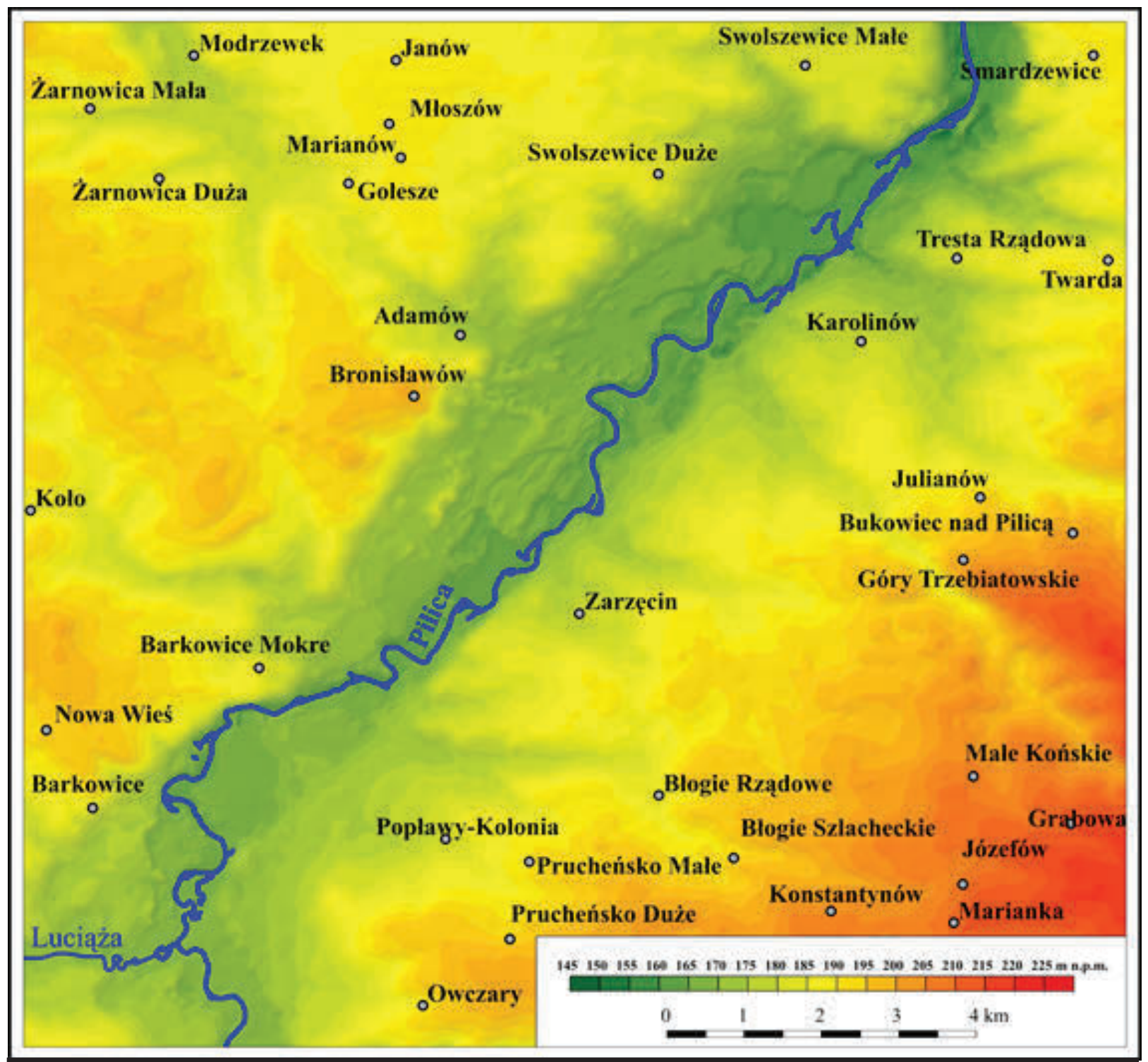

Rys. 7. Rzeźba obszaru doliny Pilicy pomiędzy Sulejowem a Smardzewicami z okresu przed budową zbiornika „Zalew Sulejowski”

Fig. 7. The relief of the Pilica valley area between Sulejow and Smardzewice from the period before the construction the Sulejowski Reservoir

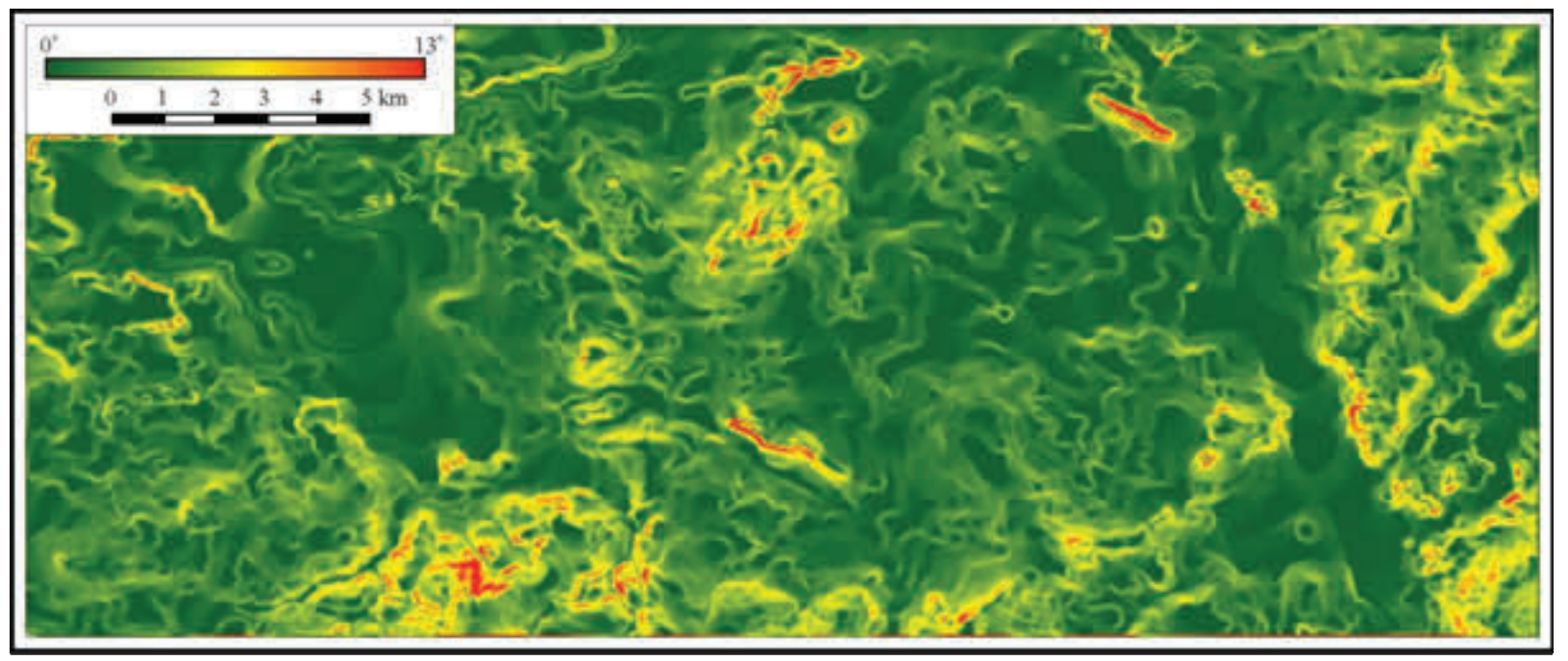

Rys 8. Mapa spadków terenu dzisiejszej KWB Bełchatów w okresie przed inwestycyjnym

Fig. 8. The slope map area of today's KWB Bełchatów in the period before the investment 


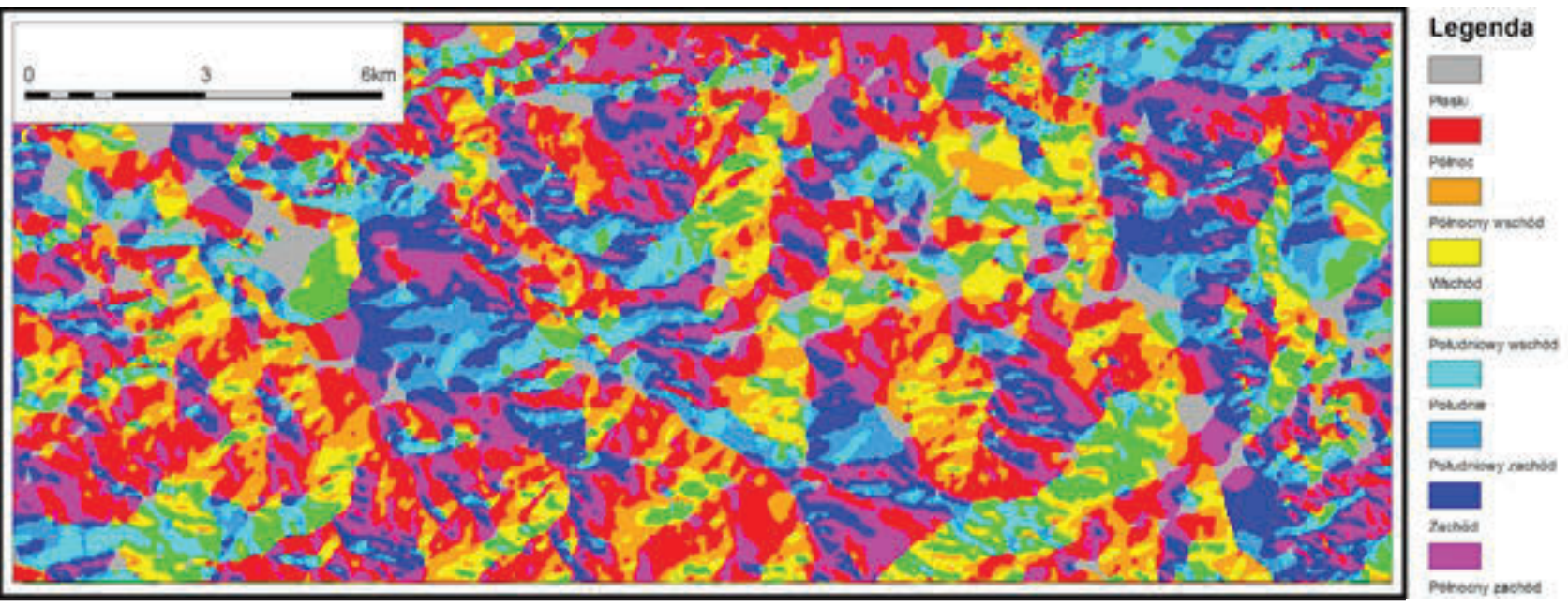

Rys 9. Mapa ekspozycji terenu dzisiejszej KWB Bełchatów w okresie przed inwestycyjnym

Fig. 9. The aspect map area of today's KWB Bełchatów in the period before the investment

\section{Podsumowanie}

Wykonane w ten sposób modele terenu oddają obraz historycznej rzeźby z okresu konstrukcji mapy, na podstawie których były opracowane. Umożliwiają wykonywanie wizualizacji za pomocą narzędzi GIS oraz badań charakteru nie istniejących dziś fragmentów powierzchni Ziemi. W zestawieniu z modelami teraźniejszymi mogą służyć analizom współkształtności powierzchni, co w tym wypadku odpowiada przemianom rzeźby terenu na danym obszarze pod wpływem procesów zarówno naturalnych, jak i antropogenicznych. Umożliwiają wyznaczenie stref erozji i akumulacji oraz ilościowego określenia rozmiarów zobrazowanego procesu. Model doliny Pilicy, którego wykonanie przedstawiono $w$ niniejszej pracy służy w badaniach przemian dna doliny rzecznej na skutek budowy jeziora zaporowego (Jaskulski, Szmidt 2014, 2015), a także wykorzystywany jest w projekcie MONSUL dotyczącym monitorowania stanu wody Zalewu Sulejowskiego realizowanego w ramach Mechanizmu Finansowego Europejskiego Obszaru Gospodarczego, Program Operacyjny PL03: „Wzmocnienie monitoringu środowiska oraz działań kontrolnych". Także drugi model, obrazujący stan rzeźby obszaru okolic KWB Bełchatów w latach 40. ubiegłego wieku zostanie wykorzystany w przyszłości badaniom antropogenicznych zmian rzeźby terenu spowodowanych działalnością górniczą.

\section{Literatura}

Badura, J., Przybylski, B., 2005. Application of digital elevation models to geological and geomorphological studies - some examples. Przegląd Geologiczny 53(10/2), 977-983.

Ewertowski, M., Tomczyk, A., 2007. Numeryczny Model Terenu i jego pochodne dla recesyjnych form młodoglaclalnych na obszarze Wielkopolski, [w:] Smolska E., Giriat D. (red.), Rekonstrukcja dynamiki procesów geomorfologicznych - formy rzeźby i osady. Uniwersytet Warszawski, Warszawa, 141-150.

IMGW 2008. Zbiornik wodny Sulejów badania sedymentacji i aktualizacja pojemności.
James, L.A., Hodgson, M.E., Ghoshal, S., Latiolais, M., 2012. Geomorphic change detection using historic maps and DEM differencing: The temporal dimension of geospatial analysis. Geomorphology 137, 181-198.

Jaskulski, M., Łukasiewicz, G., Nalej, M., 2013. Porównanie metod transformacji map historycznych (Comparison of methods for historical map transformation). Roczniki Geomatyki 11, 4(61), 41-58, http://rg.ptip. org.pl/index.php/rg/article/view/RG2013-4-JaskulskiLukasiewiczNalej.

Jaskulski, M., Szmidt, A., 2013. Ocena przydatności automatycznego wyznaczania linii szkieletowych terenu do analiz geomorfometrycznych. Acta Universitatis Lodziensis, Folia Geographica Socio-Oeconomica 14, 145-156. URI: 11089/10772.

Jaskulski, M., Szmidt, A., 2014. Transformations in morphometry of valley bottom as e result of the creation of artificial water reservoir on tne example of Sulejowskie Lake in the Light of the Chosen GIS Mathods. IGU 2014 Book of Abstracts IGU - 0524.

Jaskulski, M., Szmidt, A., 2015. Transformations in morphometry of valley bottom as a result of the creation of a reservoir illustrated with the example of Sulejów Lake. Landform Analysis 27, 15-21 (w druku).

Medyńska-Gulij, B., 2010. Perspektywa na mapach - konfrontacja metod prezentacji rzeźby terenu z wizualizacjami 3D, [w:] Żyszkowska, W., Spallek, W. (red.), Numerycznie modele w kartografii. Wrocław, 14-21.

Mitka, B., Piech, I., 2012. Modelowanie powierzchni terenu. Infrastruktura i ekologia terenów wiejskich 3/1/2012, PAN, 167-180.

Molewski, P., Juśkiewicz, W., 2014. Próba rekonstrukcji pierwotnej rzeźby obszaru Zespołu Staromiejskiego w Toruniu i jego bliskich przedmieść na podstawie geoinformacji geologicznej i historycznej. Landform Analysis 25, 115-124. DOI: 10.12657/landfana.025.010.

Nowak, T., 2015. Rzeźba terenu z okresu przedinwestycyjnego na obszarze KWB Bełchatów na podstawie Numerycznego Modelu Terenu. Maszynopis pracy magisterskiej, Katedra Geografii Fizycznej Ut.

Sibson, R., 1981. A brief description of natural neighbor interpolation, [w:] Barnett, V., Interpreting Multivariate Data, Wydawnictwo John Wiley \& Sons, Nowy Jork, USA, 21-36.

Szubert, M., 2008. Geomatyka w badaniach geomorfologicznych. Dokumentacja Geograficzna 37, 7-13.

Viesmann, S., Brüngger, A., Schenkel, R., Sidler, A., Hurni, L., 2013. Historical Maps as Source for Glacier DEM Reconstruction Mapping Mountain Dynamics: From Glaciers to Volcanoes New Zeland.

Wałek, G., 2013. Wykorzystanie programów QuantumGIS i SAGA GIS do budowy cyfrowego modelu wysokościowego zlewni Grajcarka. Acta Universitatis Lodziensis, Folia Geographica Socio-Oeconomica 14, 133-144. URI: 11089/10745.

Zasadni, J., Kłapyta, P., 2014.The Tatra Mountains during the Last Glacial Maximum. Journal of Maps, 1-17. DOI: 10.1080/17445647.2014.885854. 